\title{
Influence of the Human-Animal Relationship on Productivity and Animal Welfare in Dairy Farms
}

\author{
Martínez GM1*, Suárez VH² and Ghezzi MD³ \\ ${ }^{1}$ INTA EEA Salta, Agricultural Experimental Station Salta-INTA, Research Institute in Cerrillos, Argentina \\ ${ }^{2}$ INTA CIAP - IIACS - AISA, headquarters EEA Salta, Argentina \\ ${ }^{3}$ Faculty of Veterinary Sciences, National University of the Center of the Province of Buenos Aires, Argentina
}

Submission: May 03, 2019; Published: May 22, 2019

*Corresponding author: Martínez GM, Agricultural Experimental Station Salta-INTA, Research Institute in Cerrillos, INTA EEA Salta RN 68 km 172 - Cerrillos - Salta - Argentina

\section{Abstract}

Animal welfare is no longer a concern limited to European markets but has become important in milk production worldwide. The concept of animal welfare refers to the way in which individuals interact with their environment, including health, perceptions, mental state and other negative effects influencing the animal's physical and mental mechanisms. This concept contributes to the understanding from the animal's perspective; thus, producers have understood that what is beneficial for the animal is equally beneficial for production. Regardless of the species, every animal destined for production depends on a caretaker that ensures its welfare. For this reason, humans become part of the animal environment and its social relationships. Beneficial interactions include feeding, peaceful movement to the milking parlour, touching and calm talk, whereas social isolation, invasive or painful veterinary treatments, hitting and shouting hinder positive interactions and animal welfare. Fear generated through negative interactions leads to stressful states in the presence of humans and physiological unbalances that reduce production and immune response and predispose animals to disease acquisition. Mastitis and somatic cell count are among the main problems that can be increased due to a negative human-animal interaction. The results of this interaction are so important that they have been measured through stock people's or animal's attitudes and have been studied to qualify dairy cattle welfare in the milking parlour. This measurement has been related to milk production and good practices used in daily milking activities or in treatment of animals. The aim of the present review is to provide information on the influence of interactions between stock people and dairy cattle, the importance of those interactions for production and health, and their relationship with animal welfare in order to contribute to a better understanding of human-animal relationships.

Keywords: Human-animal interaction; Dairy cattle; Impact on dairy farm production

\section{Introduction}

Animal welfare has been defined by the World Organization for Animal Health (OIE) as the broad term used to describe how individuals cope with the environment, including their health, perceptions, comfort, and other positive or negative effects affecting an animal's physical and mental mechanisms [1]. Any animal used for production, regardless of the species, depends on the stockman. The tools and opportunities to take care of dairy cattle consist of ensuring their health; for this reason, humans become part of the animal environment and social relationships. Thus, animal behaviour is an indicator of the relationship with the production system where they inhabit and, therefore, identifying such behaviour can be a starting point for evaluating animal welfare [2].

Animal behaviour analyses reveal the type of human-animal relationship established on each farm, since each behaviour pattern is based on a previous experience [3]. Human-animal interactions are influenced by the five senses: touch, smell, taste, hearing and sight; in addition, depending on their nature, interactions can be positive, neutral or negative. Negative actions lead to aggressive responses, such as the increase in animal's fear of humans, resulting in greater flight distances and, therefore, hindering management and producing animal stress. Fear also causes damage to production and affects final milk quality [47]. The relationship between the stockman and dairy cattle has direct consequences on animal welfare and production. Hence, it is important to consider the personality traits of stockmen and the degree of work satisfaction and empathy towards animals; these traits have been shown to be crucial in the type of interaction generated [7].

\section{Animal Behaviour}

Social behaviour of cows is expressed in hierarchies, with a dominant group coexisting with one subordinate and several intermediate groups [8]. This behaviour is generally observed during feeding, when dominant cows do not let the subordinates, 
mostly heifers, feed. Dairy cows can also exhibit this dominance in the order of entrance to the milking parlour, with dominant cattle usually entering first [9]. Dominance is a stereotype of social behaviour when it results in a dominant pattern manifested by the aggressive interaction of two individuals during access to different resources [10].

While there are behavioural patterns among individuals of a single animal species, several research works have demonstrated that human-animal interactions can have different effects on welfare, behaviour, and production $[2,3,11,12]$. In animals used in production systems, the quality of interactions with humans is a determining factor in the development of fear of humans and, consequently, for welfare and productivity [13]. It has been frequently reported that animals can differentiate the caretakers by recognizing different facial features [14] and the colour of clothing [15], and therefore can relate a specific caretaker with characteristics of the type of treatment received [3,5,11,12]. Thus, animals associate their caretakers with the type of experience undergone, whether it is positive or negative $[5,16,17]$. In addition, animal behaviour will depend on the type of experience they have during a new event of similar characteristics. This type of learning is known as associative learning. Cattle have great learning capacity and good memory. Associative learning processes, such as habituation and operating conditioning, facilitate management and need to be applied daily [18].

Habituation consists of animals getting used to the persons, the places and the management routines involved in their care, so that their fear decreases. During this process, animals do not receive a reward after exhibiting the desired behaviour. During the operant conditioning process, animals are offered rewards after having exhibited the wanted behaviours, such as an attractive food or supplement for them after moving through the handling area, the pen or the milking parlour. After performing this practice, animals are expected to access the spaces more easily, since they expect to find their reward. Another example is calling the animals every time they are offered food in the feeders; thus, the animal will associate human voice with feeding. Furthermore, cattle tend to generalize the experiences with one person to other people; therefore, it is important that animals are equally well treated by all the caretakers in a dairy farm. Animals also learn to associate aversive handling with a specific place or location; hence, location may act as a cue that cows use for predicting how the stockman will act, with animals presenting agitation and fear if they have constructed negative associations with a site [19].

\section{Human Characteristics that Favour Human-Animal Interaction}

Attitude and personality are the main concepts used in psychology to explain human behaviour. The theory of "reasoned action" (TRA) proposed by Ajzen \& Fishbein [20] postulates that human attitudes are related to beliefs, social pressure, intentions and behaviour. Theory also considers that a person tends to behave favourably towards the things and activities that they enjoy doing, and unfavourably towards those things that are not pleasant. Hemsworth \& Coleman [13] propose a model for describing the human-animal interaction, in which there is a reciprocal relationship (cause-consequence) between the stockman's attitudes and the animal's response (Figure 1).

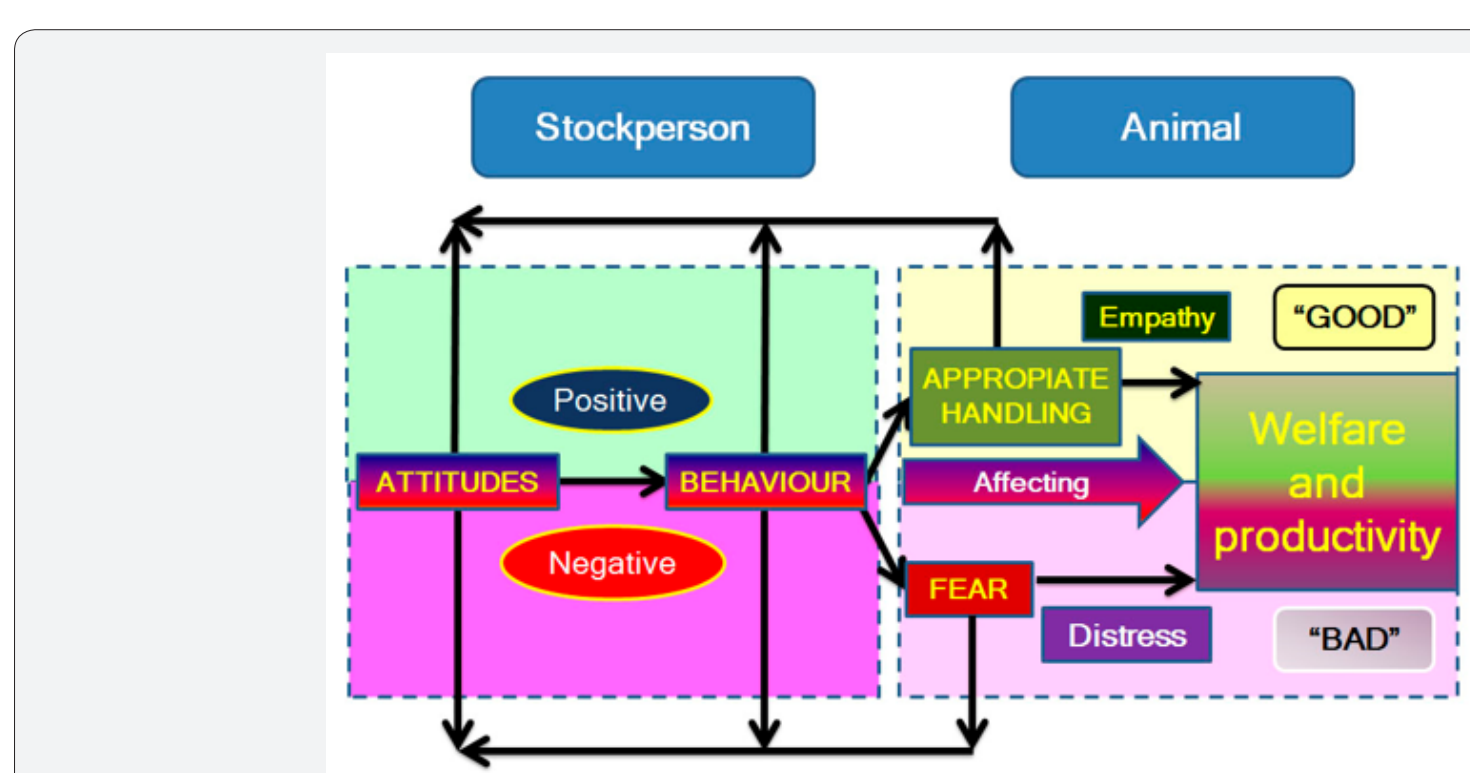

Figure1: Human-animal interaction model Adapted from Hemsworth and Coleman (1998).

Waiblinger [21] classified human-animal contact into five types:

i. Visual presence ii. Moving between the animals without physical contact, (but possibly using vocal interactions,

iii. Physical contact 
iv. Feeding (rewarding), and

v. Invasive handling (e.g. dehorning).

The relationships that can be established between stock people and dairy cows, however, are merely utilitarian, and no bond is expected to be established between them [22]. Therefore, attempts should be made to establish positive interactions, since, as shown in Figure 1, a stockman's negative attitudes towards the animals will provoke negative animal behaviours. In turn, a negative stockman's attitude will hinder herd handling, since animals will attempt to escape and avoid the person. This type of episodes will strengthen the fear toward that person and that handling type, completing a feedback cycle. By contrast, a positive feedback occurs with positive attitudes and behaviours, leading to a reduction in animal reactivity [13]. Beneficial interactions with animals include feeding and peaceful movement to the milking parlour, and touching and calm talk [23], whereas social isolation, invasive or painful veterinary treatments, hitting and shouting hinder the establishment of a positive interaction as well as animal welfare.

A stockman's personality traits (aggressiveness, kindness, self-confidence, etc.) are correlated with management success, interaction with animals, and animal productivity [23-26]. In addition, the stockman's level of empathy with animals, and the degree of satisfaction with his work and his own life quality are associated with his attitudes [7,12,25-27]. Therefore, a person that is satisfied with his job will perform his duties cheerfully, trying to learn and improve his skills. While personalities may be relatively stable in time, a person's attitude may change. Thus, providing workers with the necessary conditions for them to improve their attitudes and behaviours will result in enhanced animal productivity and welfare [28].

\section{Influence of Interaction Type on Dairy Cattle Productivity, Health and Welfare}

As mentioned above, the term interaction indicates that the parties are mutually affected. Inappropriate human-animal interactions, for example, may have negative consequences on both physiology and productivity, thereby compromising the welfare not only of animals but also of stock people, since a fearful reaction from an animal may pose a risk to human safety. Animals usually have different levels of tolerance or adaptation to diverse stress factors in their environments; when those levels are exceeded, however, the animal body reacts to return to equilibrium, i.e., homeostasis. When the biological system cannot cope with stressors, normal behavioural activity is suppressed, and therefore the animal depends on short-term integration capacity between the nervous and endocrine systems [29]. This short-term response is determined by the activation of the sympathetic nervous system and the consequent release of catecholamines from the adrenal medulla. When a long-term response is necessary, the hypothalamic-pituitary-adrenal axis is activated, and glucocorticoids are released from the adrenal gland
[30]. Increased serum glucocorticoid levels are considered stress indicators in mammals, with their levels decreasing under chronic stress [31]. Chronic stress may lead to alteration or suppression of the immune response or of certain physiological mechanisms. Thus, chronic stress can result in an increase in susceptibility to disease and negative effects on other important physiological functions, such as reproduction [31-34].

Therefore, animals that become fearful of stock people due to inadequate management may experience acute or chronic stress in the presence of humans. Fear is an emotional state induced by perception of danger [35]; thus, while fear and stress are not synonyms, the former may lead to the latter, particularly if the fear is intense, prolonged or unavoidable, causing sustained increases of corticosteroids and affecting both the protein metabolism and the immune system [36]. Bad or zero biological adaptation of animals causes physiological changes that lead to acute or chronic stress, making them susceptible to diseases, and affecting their emotional state, which may be observed in changes in behaviour. In addition, reproductive success and productive yield are compromised, which can be confirmed by lower gain and conversion indices, among others, affecting the quality of the products, such as meat and milk.

\section{Effect on Productivity and Animal Health}

Breuer [3] estimated that about $19 \%$ of the reduction in cow milk production is attributable to fear of stock people during some of the milking activities. Rosa [37] stated that the reduction in milk production associated with aversive management can reach up to $1 \mathrm{~kg} / \mathrm{cow} /$ day. Rushen [5] reported that the mere presence of a person associated with a negative experience by the animal during milking can increase residual milk. Accordingly, Waiblinger [26] found a negative correlation between fear of humans and milk production. The increase of residual milk in dairy cows would be explained by the decrease in oxytocin secretion, which may be totally or partially affected, depending on the stress level that the animal is undergoing associated with negative experience with the presence of stock people [4]. Besides variations in milk production, Breuer [3] observed differences in milk protein and fat content, depending on the type of interaction, with values of those variables being lower when the stockman's attitudes had a negative effect on the interaction. Accordingly, fat content of residual fractions and the last fractions drawn from the udder are generally four times higher than in the first portion of extracted milk.

Predisposition to and development of mastitis is closely associated with the increase of residual milk. Mastitis is an infectious-. contagious disease of the mammary glands, which develops inflammation as a response to invasion of different types of bacteria, mycoplasma, fungi, yeast and even some viruses through the teat canal. However, $90 \%$ of the clinical and subclinical cases are caused by bacteria of the genera Staphylococcus, Streptococcus, Corynebacterium and some Gram - germs [38,39]. 
Mastitis, both clinical and subclinical, is the most frequent pathology in dairy cows worldwide, affecting their welfare and causing negative effects on milk production and composition [40,41]. While mastitis can have a very low effect on total percentage of milk proteins, it produces a drastic change in composition, mainly a decrease in casein content [38,42]. Mastitis often causes a reduction in both fat and lactose content and changes in the lipid fraction composition [38,39,42]. During mastitis, the organism reacts to the presence of microorganisms by increasing the levels of somatic cells (SC), i.e. cells that are composed of an association between leukocytes and epithelial cells. The presence of leukocytes in milk is a response to inflammation that may appear due to a disease or, sometimes, a lesion, whereas the presence of epithelial cells is attributed to common desquamation of the epithelium of the mammary gland $[43,44]$.

While mastitis infections are the main factor of the increase in SC count (SCC), other factors may be involved, such as cow age, days in milk, and stressors, including diseases, lesions, hoof lesions, intense heat, long walks, mud, changes in the diet or daily routine, or chronic fear. Distress leads to an increase in SCC $[34,45]$ and, since the amount paid to the producer is related partly to the SCC, it is important to promote interactions that do not generate stress in animals. Overall health care and, particularly, prevention of hoof lesions, as well as of disturbances and intoxication from diet formulations, are ways of avoiding stressful situations and their consequences on dairy cow welfare and production. Some research works have analysed a handler's treatment to dairy cattle as a factor that predisposes cows to mastitis occurrence. Ivemeyer [34] confirmed the multifactor nature of mastitis, including factors related to the cows, their environment and the humananimal relationship. A positive and gentle treatment of cows by the stockman during milking is associated with a lower SCC and lower prevalence of quarters with intramammary inflammation. Most of the consequences of a stockman's rough treatment clearly lead to a loss of productivity and are associated with udder health [34], compromising the producer's incomes. Inflammations caused by mastitis are one of the most important causes of pain and are therefore closely associated with cow welfare $[46,47]$.

\section{Tools for Assessing the type of Human-Animal Interaction}

Human-animal interactions can be analysed by assessing both stock people and animals. Measuring human attitudes and behaviours can give a panorama of human relationships with animals and while attitudes cannot be measured directly, they can be estimated through an ad hoc questionnaire [48,49].

The tests evaluating animal responses to humans can be classified into three categories:

a. Type 1: those that evaluate responses to the presence of a human being. b. Type 2: those based on the animal response to the presence and movement of a human being.

c. Type 3: those that evaluate reactions associated with routine handling [21].

Regardless of the type of test selected, the reactions measured generally include behavioural and physiological responses. Among the tests used to evaluate dairy cows' fear of humans, the most commonly mentioned are those that measure animal response during milking (type 3) [50,51] and others that consider the principle of fear and avoidance, known as approach tests (type 2). Type 1 tests are easy to perform and provide objective results, but the animal's response is still conditioned by the stockman's behaviour. Approach tests measure an animal behaviour in the nearby presence of a human (docility test) or through objective measures (flight distance, approach distance, number of interactions, etc.). Approach tests are relatively easy to perform and interpret, but an animal's response to humans may be influenced both by the stockman and the cow's capacity of associate the stockman with previous situations, as well as the by the presence or absence of conspecifics (social environment), since the animal's degree of approach to humans will be related to its location in the hierarchical structure of the herd (dominant, intermediate, subordinate), being substantially lower in dominant cows.

Tests evaluating a herd's fear or docility are usually very simple but require correct selection and execution to obtain reliable and valid results. The review conducted by De Passillé \& Rushen [52] evidences the difficulty in developing a standardized and robustly supported test to evaluate human-animal interactions, given the great variety and diversity of tests and measures used by different researchers. Thus, the authors suggest that, for measures to be valid in a welfare inspection, they should be reliable and capable of being taken in one or several relatively short visits by persons that are not necessarily trained for the research. Thus, the chosen test should allow researchers to obtain valid indicators that can identify animal handling or welfare. We conducted a survey among stockman in charge of cow milking on 16 dairy farms in Salta, Argentina, and recorded data of the processes used during milking routine, attitude towards animals and management. Those processes were then related to cows' flight distance (type 2 test) as an indicator of the herd's fear. Wrong procedures used during milking routine determined $\left(\mathrm{R}^{2} 0.21 ; \mathrm{p}<0.02\right)$ a high percentage of animals with a flight distance above $1 \mathrm{~m}$, which is related to deficient procedures in the milking routine with cows fearful of the stockman. When the procedures of milking routine were related to the management of cows and the concepts of the stockman's in relations to animal welfare levels, a good association was also obtained $\left(\mathrm{R}^{2} 0.11 ; \mathrm{p}<0.09\right)$ between stockman's wrong procedures and their welfare concepts, with a greater proportion of fearful or frightened cows. The mentioned survey also found a significant association $\left(R^{2}\right.$ 0.40; $\left.\mathrm{p}<0.0001\right)$ between human attitude and 
milk production on the farm determined by the good practices implemented during the milking process $[53,54]$.

\section{Conclusion}

Several works have confirmed the importance of the interaction generated between humans and farmed animals, both for productivity and animal welfare. The characteristics of handler's behaviour towards cattle generate animal's responses and attitudes that can influence behaviour, productivity and health, depending on good or bad previous experiences. A stockman's work satisfaction is very important, since it favours positive attitudes, which leads to increased welfare, reducing fearful situations in cattle and risk situations for workers. Fear generated through negative interactions leads to stressful states in the presence of humans and physiological unbalances that reduce production and immune response, predisposing the animals to diseases. Mastitis and SCC are two of the main problems that can increase due to a negative human-animal interaction.

The results of human-animal interactions are so important that their measurement through caretaker's attitudes or animal behaviour in the presence of humans is used to describe animal welfare on dairy farms and analyse milk production and good practices used during milking or animal management. The importance of this interaction also lies in the fact that a producer's income depends not only on the yield obtained but also on milk quality and composition. The present review shows the importance of the cattle-stockman interaction in milk production, and dairy cows' health and welfare. The described results are only the product of preliminary studies, since there is still a long way to go towards having a better understanding of the human-animal relationship.

\section{References}

1. OIE (2004) Terrestrial Animal Health Code. Chapter 7.1. Introduction to the recommendations for animal welfare. Article 7.1.1. Definition. Thirteenth Edition. OIE, Paris, France.

2. Duncan IJH (1990) Behavioral assessment of welfare. In: Mench JA, Mayer SJ, Krulisch L (Eds.), J Anim Sci 78: 2821-2831.

3. Breuer K, Hemsworth PH, Barnetta JL, Matthewsc LR, Colemand GJ (2000) Behavioral response to humans and the productivity of commercial dairy cows. Applied Animal Behavior Science, 66: 273-288.

4. Bruckmaier RM, Blum JW (1998) Oxytocin release and milk removal in ruminants. J Dairy Sci 81: 939-949.

5. Rushen J, de Passille AMB, Munksgaard L (1999) Fear of people by cows and effects on milk yield, behavior and heart rate at milking. J Dairy Sci 82: 720-727.

6. Hemsworth PH, Coleman GJ, Barnett JL, Borg S (2000) Relationships between human-animal interactions and productivity of commercial dairy cows. J Anim Sci 78: 2821-2831.

7. Hemsworth PH, Coleman GJ, Barnett JL, Borg S, Dowling S (2002) The effects of cognitive behavioral intervention on the attitude and behavior of stockpersons and the behavior and productivity of commercial dairy cows. J Anim Sci 80: 68-78.

8. Fraser AF, Broom DM (1990) Farm animal behavior and welfare. Bailliere Tindall $3^{\text {rd }}$ Edición.
9. Sauter-Louis CM, Chesterton N, Pfeiffer DU (2000) Can we predict, based on dominance structure, which cows will become lame in a new zealand dairy herd? Proceedings of the $9^{\text {th }}$ International Symposium on Veterinary Epidemiology and Economics.

10. Collis KA (1976) An investigation of factors related to the dominance order of a herd of dairy cows of similar age and breed. Appl Anim Ethol 2: $167-173$.

11. Pajor EA, Rushen J, De Passilé AMB (2000) Aversion learning techniques to evaluate dairy cattle handling practices. Applied Animal Behaviour Science 69: 89-102.

12. Hanna D, Sneddon IA, Beattie VE (2009) The relationship between the stockperson's personality and attitudes and the productivity of dairy cows. Animal 3(5): 737-743.

13. Hemsworth PH, Coleman GJ (1998) Human-livestock interactions: the stockperson and the productivity and welfare of intensively farmed animals. CAB International, London, UK, pp. 140.

14. Rybarczyk P, Koba K, Rushen J, Tanida H, de Passillé AM (2001) Do cows recognize people by their faces? Applied Animal Behaviour Science 74: 175-189.

15. Rybarczyk P, Rushen J, de Passillé AM (2003) Recognition of people by dairy calves using color of clothing. Applied Animal Behaviour Science 81: 307-319.

16. Boivinb X, Garel JP, Mante A, Le Neindre P (1998) Beef calves react differently to different handlers according to the test situation and their previous interactions with their caretaker. Applied Animal Behavior Science 55(3-4): 245-257.

17. Munksgaard L, de Passillé AM, Rushen J, Herskin MS, Kristensen AM (2001) Dairy cows' fear of people: social learning, milk yield, and behavior at milking. Applied Animal Behavior Science 73(1): 15-26.

18. Paranhos da Costa MJR, Tarazona Morales AM (2011) Practical approach on how to improve the welfare in cattle. Rev Colomb Cienc Pecu 24: 3.

19. Rushen J, Munksgaard L, de Passill AM, Jensen MB, Thodberg K (1998) Location of handling and dairy cows' responses to people. Applied Animal Behaviour Science 55: 259-267.

20. Ajzen I, Fishbein M (1980) La comprensión de las actitudes y la predicción de la conducta social. Nueva Jersey: Prentice-Hall, Fundación Purina, Barcelona, Spain, pp. 278.

21. Waiblinger S, Boivinb X, Pedersenc V, Tosid MN, Janczake AM, et al. (2006) Assessing the human-animal relationship in farmed species: A critical review. Applied Animal Behaviour Science 101: 185-242.

22. Katcher AH (1993) El hombre y el entorno viviente: una excursión a través del tiempo cíclico. In: Katcher AH, Beck AM (Eds.), Los animales de compañía en nuestra vida. Nuevas perspectivas.

23. Seabrook MF (1994) Psychological interaction between the milker and the dairy cow. In: Bucklin R (Eds.), Dairy systems for the $21^{\text {st }}$ century, p. 49-58.

24. Seabrook MF (1972) A study to determine the influence of the herdsman's personality on milk yield. J Agric Labor Sci 1: 45-49.

25. Waiblinger S, Menke C (1999) Influence of herd size on human-cow relationships. Anthrozoös 12: 240-247.

26. Waiblinger ThS, Menke C, Colemane C (2002) Relationship between attitudes, personal characteristics and behaviour of stockpeople and subsequent behaviour and production of dairy cows. Applied Animal Behaviour Science 79(3): 195-219.

27. Hemsworth PH (2003) Human-animal interactions in livestock production. Applied Animal Behavior Science 81: 185-198. 
28. Costa PT, Mc Crae RR (1986) Personality stability and its implications for clinical psychology. Clin Psychol Rev 6: 407-423.

29. Zulkifli I (2013) Review of human-animal interactions and their impact on animal productivity and welfare. J Anim Sci Biotechnol 4(1): 25

30. Cunningham J (1999) Fisiología veterinaria (2 $2^{\text {nd }}$ edn), Mc Graw Hill Interamericana pp. 763.

31. Breazile J (1988) The physiology of stress and its relationship to mechanisms of disease and therapeutics. Food Animal Practice 4(3): 441-480.

32. Chrousos GP, Torpy DJ, Gold PW (1998) Interactions between the Hypothalamic-Pituitary Adrenal Axis and the Female Reproductive System: Clinical Implications. Ann Intern Med 129: 229-240.

33. Dobson H, Smith RF (2000) What is stress, and how does it affect reproduction? Anim Reprod Sci 60(61): 743-752

34. Ivemeyer S, Knierim U, Waiblinger S (2011) Effect of human-animal relationship and management on udder health in Swiss dairy herds. J Dairy Sci 94(12): 5890-5902.

35. Boissy A (1995) Fear and fearfulness in animals. Quart. Rev Biol 70: 165-191.

36. Hemsworth PH, Barnett JL, Coleman GJ, Hansen C (1989) A study of the relationships between the attitudinal and behavioral profiles of stockpersons and the level of fear of humans and reproductive performance of commercial pigs. Appl Anim Behav Sci 23: 301-314.

37. Rosa MS (2002) Interação entre retireiros e vacas leiteiras na ordenha. 52f. Dissertação (Mestrado em Zootecnia) - Faculdade de Ciências Agrárias e Veterinárias, Universidade Estadual Paulista, Jaboticabal, SP.

38. Kitchen BJ (1981) Bovine mastitis: Milk compositional changes and related diagnostic tests. J Dairy Res 48: 167-188.

39. Needs EC, Anderson M (1984) Lipid composition of milk from cows with experimentally induced mastitis. J Dairy Res 51: 239-249.

40. De Graves FJ, Fetrow J (1993) Economics of mastitis and mastitis control. Vet Clin North Am Food Anim Pract 9: 421-434.

41. Hortet P, Seegers H (1998) Calculated milk production losses associated with elevated somatic cell counts in dairy cows: review and critical discussion. Vet Res 29: 497-510.
42. Schultz LH (1977) Somatic cell in milk-physiological aspects and relationship to amount and composition of milk. J Food Prot 40: 125131.

43. Eberhart RJ, Hutchinson LJ, Spencer SB (1982) Relationships of bulk tank somatic cell counts to prevalence of intramammary infection and to indices of herd produdion. J Food Rot 45: 1125-1128.

44. Harmon RJ (1994) Physiology of mastitis and factors affecting somatic cell counts. J Dairy Sci 77(7): 2103-2112.

45. Reneau JK (1986) Effective use of dairy herd improvement somatic cell counts in mastitis control. J Dairy Sci 69: 1708-1720.

46. Leslie KE, Petersson-Wolfe CS (2012) Assessment and management of pain in dairy cows with clinical mastitis. Vet Clin North Am Food Anim Pract 28(2): 289-305.

47. Medrano Galarza C, Gibbons J, Wagner S, de Passillé AM, Rushen J (2012) Behavioral changes in dairy cows with mastitis. J Dairy Sci 95(12): 6994-7002.

48. Rennie LJ, Bowel VA, Dearing JM, Haskell MJ, Lawremce AB (2003) A study of three methods used to assess stockmanship on commercial dairy farms: can these become effective welfare assessment techniques? Animal Welfare 2: 591-597.

49. Bertenshaw C, Rowilinson P (2009) Exploring stock managers perceptions of the Human-Animal relationship on dairy farms and an association with milk production. Anthrozoös, 22: 59-69.

50. Boivinb X, LeNeindre P, Chupin JM (1992) Establishment of cattlehuman relationships. Appl Anim Behav Sci 32: 325-335.

51. Munksgaard L, De Passille AM, Rushen J, Thodberg K, Jensen MB (1997) Discrimination of people by dairy cows based on handling. J Dairy Sci 80: $1106-1112$

52. De Passillé AM, Rushen J (2005) Can we measure human-animal interactions in on-farm animal welfare assessment? Some unresolved issues. Appl Anim Behav Sci 92: 193-209.

53. Martínez GM, Suarez VH, Bertoni EA (2016) Interacción humano - animal: impacto productivo en rodeos lecheros. Resúmenes 39 Congreso Argentino de Prod. Animal, Tandil, Bs As, Argentina.

54. Peaker M, Faulkner A (1983) Soluble milk constituents. Proc Nutr Soc 42: 419-425.

\section{Your next submission with Juniper Publishers} will reach you the below assets 